Review Article

\title{
Interactions between plant hormones and heavy metals responses
}

\author{
Lauro Bücker-Neto ${ }^{1}$, Ana Luiza Sobral Paiva ${ }^{2}$, Ronei Dorneles Machado ${ }^{2}$, Rafael Augusto Arenhart ${ }^{3}$ and
} Marcia Margis-Pinheiro ${ }^{2}$

${ }^{1}$ Departamento de Biologia, Universidade Estadual do Centro-Oeste (UNICENTRO), Guarapuava, PR, Brazil.

${ }^{2}$ Programa de Pós-Graduação em Genética e Biologia Molecular, Departamento de Genética, Universidade

Federal do Rio Grande do Sul (UFRGS), Porto Alegre, RS, Brazil.

${ }^{3}$ Empresa Brasileira de Pesquisa Agropecuária - Centro Nacional de Pesquisa de Uva e Vinho, Bento Gonçalves, RS, Brazil.

\begin{abstract}
Heavy metals are natural non-biodegradable constituents of the Earth's crust that accumulate and persist indefinitely in the ecosystem as a result of human activities. Since the industrial revolution, the concentration of cadmium, arsenic, lead, mercury and zinc, amongst others, have increasingly contaminated soil and water resources, leading to significant yield losses in plants. These issues have become an important concern of scientific interest. Understanding the molecular and physiological responses of plants to heavy metal stress is critical in order to maximize their productivity. Recent research has extended our view of how plant hormones can regulate and integrate growth responses to various environmental cues in order to sustain life. In the present review we discuss current knowledge about the role of the plant growth hormones abscisic acid, auxin, brassinosteroid and ethylene in signaling pathways, defense mechanisms and alleviation of heavy metal toxicity.
\end{abstract}

Keywords: ABA, auxin, brassinosteroid, ethylene, abiotic stress.

Received: April 02, 2016; Accepted: December 21, 2016.

\section{Introduction}

During their lifetime, plants are affected by several environmental challenges that threaten survival and negatively influence their growth and productivity. Understanding how plants can translate the signals from an everchanging environment into physiological behavior is essential for reducing harmful effects caused by abiotic stresses, such as heavy metal toxicity.

Currently, the contamination of natural ecosystems by heavy metals represents a worldwide environmental concern, endangering agricultural systems (Recatala et al., 2006). In developing countries, this problem has arisen from long-term use of untreated wastewater for irrigation, leading to increased concentrations of heavy metals in soils (Arora et al., 2008; Lu et al., 2015). This prevents plants from reaching their maximum genetic potential for growth, development and reproduction.

Once deposited on the ground, plants are able to take up these elements from the soil, and introduce them into the food chain, raising the risk of metal toxicity concerns for

Send correspondence to Marcia Margis Pinheiro. Departamento de Genética, Universidade Federal do Rio Grande do Sul, Avenida Bento Gonçalves 9500, 91501-970, Porto Alegre, RS, Brazil. E-mail: marcia.margis@ufrgs.br humans and animals (Vincevica-Gaile and Klavins, 2012; Roy and McDonald, 2015).

Among heavy metals, some are essential for plant growth and development as micronutrients elements and play an important role in metabolism. Copper and zinc, for example, are critical for the action of $\mathrm{Cu}$ - and $\mathrm{Zn}$-dependent enzymes involved in several physiological processes. However, at elevated concentrations, heavy metals negatively affect the morphology, physiology and biochemistry of plants (Gangwar et al., 2010; Zhang et al., 2011; Gautam et al., 2016; Ivanov et al., 2016; Mathur et al., 2016). It has been shown that heavy metals also reduce biomass accumulation (Ghavri and Singh, 2012; Zhao et al., 2012; Beyer et al., 2013; Ebbs et al., 2015) as a result of adverse effects upon key metabolic processes such as photosynthesis (Rodriguez et al., 2012), mineral nutrition (Vernay et al., 2007) and interactions with water (Mukhopadhyay and Mondal, 2015).

Besides the direct impact of heavy metals on plants, they can also cause cell toxicity by overproduction of reactive oxygen species (ROS), which impairs antioxidant defense systems and causes oxidative stress (Vanhoudt et al., 2010; Thounaojam et al., 2012; Anjum et al., 2016; Nanda and Agrawal, 2016; Rui et al., 2016). 
In plant cells, aerobic reactions such as respiration or photosynthesis lead to ROS production. These ROS, such as hydroxyl, hydrogen peroxide or superoxide, can damage biological molecules, including lipids, DNA and proteins (Noctor and Foyer, 1998). Rates of ROS generation and cellular ROS levels both increase quickly when plants are subjected to abiotic or biotic stress.

Bioactive-metals, based on their physicochemical properties, are divided into two groups: redox metals such as $\mathrm{Cr}, \mathrm{Cu}, \mathrm{Mn}$, and $\mathrm{Fe}$, and non-redox metals such as $\mathrm{Cd}$, $\mathrm{Ni}, \mathrm{Hg}, \mathrm{Zn}$, and $\mathrm{Al}$. The redox metals can directly generate oxidative injury in plants through Haber-Weiss and Fenton reactions, which leads to production of ROS, resulting in oxidative stress via disequilibrium between prooxidant and antioxidant homeostasis (Jozefczak et al., 2012). In contrast, non-redox metals indirectly act as oxidative stressors by several mechanisms including glutathione depletion, binding to sulfhydryl groups of proteins, inhibiting antioxidative enzymes or inducing ROS-producing enzymes like NADPH oxidases (Bielen et al., 2013). Thus, high concentrations of contaminants affect plants from molecular to physiological levels. However, the precise mechanisms involved in these processes are not well understood.

Previous studies have shown that exogenous application of plant growth hormones (also known as plant hormones or phytohormones) can improve protection against heavy metal toxicity (Al-Hakimi 2007; El-Monem et al., 2009; Zhu et al., 2012; Agami and Mohamed 2013; Zhu et al., 2013; Masood et al., 2016). Acting as chemical messengers with highly complex regulation, these molecules allow plants to retain growth plasticity during development and collectively are probably the main means by which plants respond to abiotic and biotic stresses (Nishiyama et al., 2011; Chan 2012; Colebrook et al., 2014; Xu et al., 2016).

In plants, the chelation and sequestration of heavy metals by the best-characterized ligands phytochelatin and metallothionein is an important mechanism in the uptake and accumulation of both essential and nonessential heavy metals. These metal-binding cysteine-rich proteins hammer out complexes that accumulate in the vacuole and ultimately alleviate metal toxicity (Clemens, 2001; Clemens and $\mathrm{Ma}, 2016)$. There is also some evidence that phytohormones can be involved in phytochelatin biosynthesis. In the algae Chlorella vulgaris, brassinosteriods increased the total phytochelatin content under lead stress (Bajguz, 2002). In the same way, it has been suggested that there is a participation of abscisic acid in the regulation of phytochelatin synthase in potato tubers (Stroinski et al.,, 2010). Although possible, a clear link between heavy metals, hormonal pathways and metal-binding ligands in plants still needs to be explained.

In view of the significance of several phytohormones such as gibberellic acid and cytokinin as crucial key players in metal stress mitigation, (El-Monem, 2009; Zhu et al., 2012; Masood et al., 2016; Al-Hakimi 2007; Gangwar et al., 2010), this review discusses recent discoveries related to heavy metal contamination and the role of three wellstudied plant hormones (abscisic acid, auxin and ethylene). Also, we present the new findings related to the plant steroid hormone brassinosteroid, taking into account their potential significance in signaling, defense mechanisms and alleviation of the toxic effects of heavy metal exposure.

\section{Abscisic acid}

Abscisic acid (ABA) is a multifunctional phytohormone that plays an important role during many stages of a plant's life cycle, including seed development and dormancy (Nambara et al., 2010; Finkelstein 2013). This hormone has been linked with tolerance to adverse environmental conditions, and its signaling pathway is a central regulator of abiotic stress response in plants (Bartels and Sunkar, 2005; Tuteja, 2007; Danquah et al., 2014).

ABA concentration in plant tissues is known to increase after heavy metal exposure, suggesting an involvement of this phytohormone in the induction of protective mechanisms against heavy metal toxicity (Rauser and Dumbroff, 1981; Poschenrieder et al., 1989; Hollenbach et al., 1997).

It was shown that cadmium $(\mathrm{Cd})$ treatment leads to increased endogenous ABA levels in roots of Typha latifolia and Phragmites australis (Fediuc et al., 2005), in potato tubers (Stroinski et al., 2010) and also in rice plants (Kim et al., 2014). The same effect was verified in several other studies. When mercury $(\mathrm{Hg}), \mathrm{Cd}$ and copper $(\mathrm{Cu})$ solutions were applied to wheat seeds during germination, ABA levels increased (Munzuro et al., 2008). In cucumbers, seed germination decreased and ABA content increased under $\mathrm{Cu}^{2+}$ and zinc $\left(\mathrm{Zn}^{2+}\right)$ stress (Wang et al., 2014c). Similarly, augmented amounts of ABA were detected in germinating chickpea (Cicer arietinum) seeds under lead $(\mathrm{Pb})$ toxicity conditions (Atici et al., 2005), as well as in crowberries (Empetrum nigrum) exposed to $\mathrm{Cu}$ and nickel (Ni) (Monni et al., 2001).

Transcriptome analysis of a rice under arsenic (As) stress has revealed strong expression of ABA biosynthesis genes $O s N C E D 2$ and $O s N C E D 3$, as well as the up-regulation of four ABA signaling genes under metal stress (Huang et al., 2012). In a pioneering approach, Lin et al. (2013) used a whole-genome array to perform a transcriptomic analysis of rice roots exposed to vanadium (V) and showed that this metal triggered the expression of genes associated with signaling and biosynthesis of ABA.

The complex regulation of $\mathrm{ABA}$ is mediated by three main components of its signaling pathway, the PYL/PYR/RCAR, PP2C and SnRK2. In an attempt to clarify the transcriptional regulation of ABA signal transduction during cucumber seed germination under $\mathrm{Cu}^{2+}$ and $\mathrm{Zn}^{2+}$ exposure, Wang et al. (2014c) identified nine $P Y L$, three $P P 2 C$ and two $S n R K 2$ genes that are putatively involved in ABA signal transduction. The expression pat- 
terns of these genes were also investigated, and the results showed that gene expression varied with the treatment being used. However, further studies are necessary in order to better understand how core component genes of ABA signal transduction mediate heavy metal stress through gene expression induction.

Since the ABA concentration increases in response to heavy metal stress, its potential role as a mediator of $\mathrm{Cd}$ induced phytotoxicity was examined (Sharma and Kumar, 2002). Results obtained from ABA-deficient and ABAinsensitive mutants exposed to $\mathrm{Cd}$ ruled out the involvement of this phytohormone in coordinating Cd-imposed inhibitory effects on early growth.

Despite a lack of knowledge regarding the way in which the ABA signaling pathway changes in response to heavy metal exposure, a series of results indicate a strong correlation between high levels of ABA and a decrease in plant stress. Furthermore, some evidence has shed light on the functional significance of elevated hormone concentrations in plants exposed to heavy metal toxicity.

ABA is normally considered a signaling compound, which can be extracted from roots subjected to drought conditions. Transported via xylem sap to the guard cells, where it closes stomata, this phytohormone prevents a decline in water potential and contributes to the plant's adaptation to unfavorable conditions (Sauter et al., 2001; Wilkinson and Davies 2002; Pantin et al., 2013). It is well established that exposure to toxic metal concentrations impairs plant water balance (Rauser and Dumbroff, 1981; Schat et al., 1997; Mukhopadhyay and Mondal, 2015). Therefore, ABA, in this context, could play an important role in the protection against abiotic stress.

Nickel and zinc treatments have been shown to decrease water potential and stomatal conductance of 10 day-old white bean seedlings, whilst ABA levels increased (Rauser and Dumbroff, 1981). A similar finding was reported in Brassica juncea under $\mathrm{Cd}^{2+}$ exposure (Salt et al., 1995). Cd-treated white bean seedlings showed decreased relative water uptake rate whilst stomatal resistance and ABA content increased (Poschenrieder et al., 1989). It has previously been suggested that drought resistance could help plant survival in contaminated areas (Pandolfini et al., 1996).

It is possible that ABA-induced stomatal closure causes a suppression of transpirational flow, resulting in a restriction of root-to-shoot translocation of metals. Previously it was reported that $\mathrm{Cd}$ (Yeh et al., 2003) and $\mathrm{Cu}$ (Yeh et al., 2004) treatments boost mitogen-activated protein kinase (MAPK) signaling in rice, and that an increase in $\mathrm{ABA}$ content in specific rice varieties is closely related to $\mathrm{Cd}$ tolerance in seedlings (Hsu and Kao, 2003). More recently, Yeh et al. (2007) showed higher levels of ROS and calcium $\left(\mathrm{Ca}^{2+}\right)$ in the same Cd-tolerant rice seedlings. These results indicate that roots under heavy metal exposure accumulate $\mathrm{ROS}$ and $\mathrm{Ca}^{2+}$, which in turn activate MAP kinase, providing $\mathrm{Cd}$ tolerance. It is already known that ABA is able to induce transient MAP kinase activity (Knetsch et al., 1996; Burnett et al., 2000), and that ABA signaling seems not to be required for ROS production, suggesting that ROS may be upstream of ABA biosynthesis (Galvez-Valdivieso et al., 2009). Despite the progress achieved, more work is required in order to unravel the role of ABA in MAP kinase activation in response to heavy metal toxicity.

Rubio et al. (1994) showed that exogenous ABA applications affected the transport of $\mathrm{Cd}$ and $\mathrm{Ni}$ to the shoots, resulting in a higher percentage of metals in the root. In Arabidopsis thaliana, the exogenous hormone limited the root-to-shoot translocation of Cd (Perfus-Barbeoch et al., 2002). ABA restriction of heavy metal transport to the shoots may be of practical importance, at least for plants growing in Ni-polluted soils, since it is known that this metal can accumulate in fruits and seeds due to its high mobility in the phloem (Rubio et al., 1994).

There is also some evidence that ABA's potential role in plant response to heavy metal stress is related to growth inhibition. Moya et al. (1995) showed that rice cultures supplied with ABA displayed enhanced heavy metal toxicity, causing growth inhibition of young leaves and the translocation of storage products from source to sink organs. This finding is in accordance with previous observations of phloem-loading inhibition by ABA (Vreugdenhil, 1983), which could account for the accumulation of assimilates in the source and subsequent inhibition of plant growth. This process may be an adaptation to maintain viability under adverse conditions, and further enable recovery once the toxin is eliminated from the environment.

In combination, these studies suggest that ABA may be a crucial player in plant response to heavy metal toxicity. However, further studies are required in order to determine how this plant growth hormone guides adaptation under challenging conditions. Some interactions between ABA and heavy metals are shown in Figure 1A.

\section{Auxin}

The plasticity of plant development and its response to a diversity of environmental cues including the finetuning of stress management indicates that regulatory processes are very complex. Among these environmental situations faced by plants, the interaction between auxin homeostasis and heavy metal toxicity is of particular interest, once this phytohormone (representative molecule indole-3-acetic acid, IAA) is often reported as an important mediator in several aspects of plant growth and development.

Inside the cell, the hormone promotes the degradation of AUX/IAA transcriptional repressors that are associated to ARFs (auxin responsive factors) and thus inhibit the transcription of auxin-responsive genes ultimately guiding 


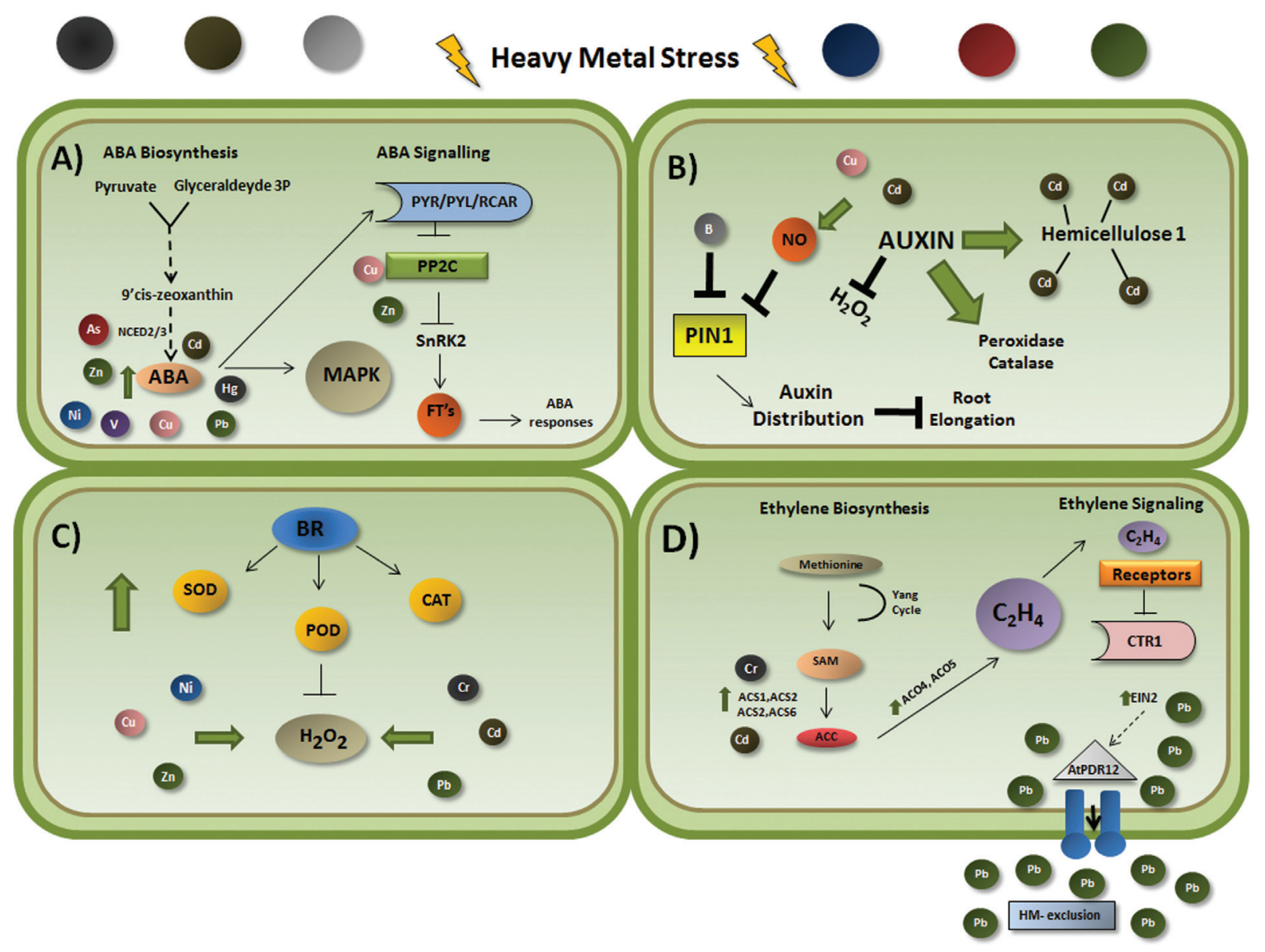

Figure 1 - Schematic representation showing some interactions between the plant hormones abscisic acid (A), auxin (B), brassinosteroids (C) and ethylene (D) under heavy metal exposure. (A) $\mathrm{Cd}, \mathrm{Cu}, \mathrm{Hg}, \mathrm{Ni}, \mathrm{Pb}$ and $\mathrm{Zn}$ treatments increase endogenous levels of ABA. Under As stress, NCED2 and NCED3 (ABA biosynthesis genes) are up-regulated. Vanadium (V) is also shown to trigger the expression of genes associated with ABA signaling and biosynthesis. The genes $P Y L, P P 2 C$ and $S n R K 2$ that are putatively involved in ABA signal transduction were identified under $\mathrm{Cu}$ and $\mathrm{Zn}$ exposure. (B) Under B starvation PIN1 changes auxin distribution and possibly inhibits root elongation. Cd induces NO accumulation, which represses auxin transport and reduces root meristem size. $\mathrm{NO}$ is also involved in the auxin signaling pathway in response to $\mathrm{Cu}$ exposure. Under $\mathrm{Cd}$ stress, an auxin conjugate (IAA-Asp) modulates catalase and peroxidase activity and decreases hydrogen peroxide concentration. In the same condition, auxin (NAA) increases hemicellulose 1 content and more Cd is fixed in the roots. (C) BRs induce SOD, CAT and POD activities, protecting plants against heavy metal toxicity. (D) $A C S$ and $A C O$ expression leads to higher production of ethylene. ACS2 and $A C S 6$ are regulated by MPK3/MPK6 at transcriptional and translational levels. MPK3 and MPK6 phosphorylate the transcription factor WRKY33, which in turn regulates ACS2 and ACS6 gene expression. The WRKY33 protein also binds directly to ACS2 and ACS6 promoters. EIN2 is an important component of the ethylene signaling pathway and acts as a transducer of stress response. Lead treatment increased the transcript levels of EIN2 in Arabidopsis seedlings under heavy metal exposure. It has been suggested that EIN2 regulates AtPDR12, an $\mathrm{ABC}$ membrane-transporter that excludes $\mathrm{Pb}$ and $\mathrm{Pb}$-containing toxic compounds from the cytoplasm. Dashed black line indicates possible regulation. Arrows and T-bars represent positive and negative regulation, respectively. Green arrows indicate increased levels. As, arsenic; $\mathrm{B}$, boron; $\mathrm{Cd}$, cadmium; Cr, chromium; $\mathrm{Cu}$, copper; $\mathrm{Hg}$, mercury; $\mathrm{Ni}$, nickel; $\mathrm{Pb}$, lead; $\mathrm{Zn}$, zinc; $\mathrm{V}$, vanadium; FT's, transcription factors; NO, nitric oxide; BRs, brassinosteroids; SOD, superoxide; CAT, catalase; POD, peroxidase; ACS, ACC synthetase; ACO, ACC oxidase.

modifications in plant physiology (Vanneste and Friml, 2009).

Auxin metabolism and dynamic polar transport distribution within the plant can be modulated by heavy metal stimuli. Results obtained from a range of heavy metal concentrations in DR5:GUS reporter line indicated that hormone accumulation and patterning in Arabidopsis seedling is treatment-dependent (Wang et al., 2014a), and an important role has been credited to the PINFORMED1 (PIN1) protein, an auxin efflux carrier for root meristem growth/maintenance under normal conditions. According to Yuan et al. (2013), when compared to DR5rev::GFP plants, Cu-treated pin1 DR5rev::GFP mutants did not show enhanced auxin activity in both the meristem and elongation zones, indicating that PIN1 is involved in hormone distribution under heavy metal stress conditions. In a similar way, auxin distribution is also altered under boron (B) starvation, which leads to PIN1 down-regulation and possible inhibition of root elongation (Li et al., 2015). This effect in root elongation could be an indirect effect caused by the crosstalk between auxin and other hormones, such as ethylene. As reported by Ruzicka et al., (2007), ethylene induces the expression of genes involved in auxin biosynthesis and stimulates the auxin transport toward the elongation zone, 
regulating its response and consequently root elongation. In Arabidopsis plants exposed to boron deficiency, auxin, ethylene and ROS participate together in a signaling pathway, acting in the reduction of root cell elongation (CamachoCristóbal et al., 2015). In addition, there are many examples, explored later in this review, showing that heavy metal toxicity can induce ethylene accumulation, which suggests a possible relation between auxin and ethylene signaling under heavy metal stress.

The roles of nitric oxide (NO) and auxin in Cdmediated inhibition of Arabidopsis root meristem growth has also been investigated (Yuan and Huang, 2016) and the results indicate that $\mathrm{Cd}$ induced $\mathrm{NO}$ accumulation, which in turn repress auxin transport, decreasing its levels in the root apex and ultimately reducing root meristem size. It is interesting to note that $\mathrm{NO}$ was previously shown to be involved in the auxin signaling pathway under $\mathrm{Cu}$ stress conditions (Peto et al., 2011).

Generally, heavy metal stress leads to a decrease in endogenous levels of auxins. For example, arsenic (As) is able to alter levels of three auxins (IAA, NAA, and indole3-butyric acid, IBA) in Brassica juncea (Srivastava et al., 2013). In another case, short-term cadmium treatment disturbed IAA homeostasis in barley root tips (Zelinová et al., 2015). Previous work also indicates that Cadmium (Cd) suppresses primary root elongation in Arabidopsis (Besson-Bard et al., 2009).

Despite the detrimental effect of heavy metal in auxin metabolism, it has been reported that exogenous application of these phytohormones can rescue the endogenous levels of the auxins. An increase in the biomass of roots and stems of sunflower (Helianthus annuиs) plants grown in soil moderately contaminated with lead $(\mathrm{Pb})$ was observed after the addition of the phytohormone IAA (Liphadzi et al., 2006). Exogenous supply of IAA also improved the growth of Brassica juncea exposed to As (Srivastava et al., 2013). In the same way, the application of different levels of L-TRP (a precursor of auxin) to the roots of rice seedlings growing in contaminated soil enhanced plant growth and yield under $\mathrm{Cd}$ stress, when compared to untreated seedlings in $\mathrm{Cd}$-contaminated pots without this auxin precursor (Farooq et al., 2015).

Some recent approaches showed that this synergistic or additive interaction between heavy metal and auxin can be used as a protective mechanism against toxicity in crop plants or as a useful tool in phytoremediation programs for detoxification of polluted areas. Tandon et al. (2015) evaluated the application of six concentrations of two representative natural auxins (IAA and IBA), and a synthetic auxin (1-Naphathaleneacetic acid), in wetland and non-wetland plant species in a water environment. The authors showed that exogenous auxin supply increased phytoremediation efficiency in wastewater treatment. Similarly, Pandey and Gupta (2015) studied the effect of the co-application of selenium (Se) and auxin on morphological and biochemical characteristics in rice seedlings exposed to As stress. When used together, Se and auxin were more effective in reducing As-induced stress compared to individual treatments.

Although the exogenous addition of auxin or stimulation of endogenous levels prevents growth inhibition and increase heavy metal tolerance, the mechanism guiding the process is still poorly understood. It is possible that there is a relationship between hormones and miRNAs under heavy metal exposure (Srivastava et al., 2013).

In another study, Ostrowski et al. (2016) showed that IAA-Asp (an auxin conjugate) affects pea responses to $\mathrm{Cd}$ by modulating catalase and peroxidase activity, as well as inducing protein carbonylation and decreasing hydrogen peroxide concentration.

There is also evidence indicating that auxins can promote modification of membrane properties, thereby alleviating toxic effects of heavy metal exposure. A mixture containing lead $\left(\mathrm{Pb}^{2+}\right)$ and IAA or naphthalene acetic acid (NAA - another member of the auxin family) has been proposed to induce decreased disorder of membrane organization, and as a consequence, reduce heavy metal toxicity (Hac-Wydro et al., 2016).

It has also been suggested that hemicellulose 1 in the cell wall is a key player in heavy metal detoxification. Under $\mathrm{Cd}^{2+}$ exposure, NAA increases metal retention in roots by fixing it to hemicellulose (Zhu et al., 2013). Exogenous NAA enhances hemicellulose 1 content and consequently the amount of $\mathrm{Cd}^{2+}$ fixed in the roots. In this way, auxininduced alleviation of $\mathrm{Cd}^{2+}$ toxicity in Arabidopsis is mediated by increased levels of hemicellulose 1 and metal fixation in the root, thus reducing the translocation of $\mathrm{Cd}^{2+}$ from roots to shoots.

Apart from deleterious effects in auxin homeostasis, it is interesting to note that the interaction between heavy metals and the phytohormone seems to be critical for survival and reproduction of some organisms. It was recently reported that the metallophyte (tolerant to high concentrations of heavy metals) moss Scopelophila cataractae requires a $\mathrm{Cu}$-rich environment to maintain its life cycle. Under this "favorable" condition, auxin accumulates and in turn activates genes required for optimal growth and cell differentiation, although the precise mechanism is not yet elucidated (Nomura et al., 2015).

These studies indicate a complex regulation of endogenous auxin in response to heavy metal exposure (Figure 1B). It is possible to speculate that several crosstalk may act concomitantly in a not-well understood signaling pathway and that a better comprehension of these processes is critical to increase the knowledge on the regulation of metal homeostasis in plants.

\section{Brassinosteroids}

Plant steroids (brassinosteroids - BRs) regulate cell expansion and elongation, photomorphogenesis, flowering, male fertility, seed germination, vascular differentia- 
tion, plant architecture, stomata formation and senescence in plants (Mandava, 1988). Sixty BRs have been identified so far and are classified according to the number of carbons in their structure (Vardhini, 2014). Brassinolide (BL), 28homobrassinolide (28-HomoBL) and 24-epibrassinolide (24-EpiBL) are the bioactive BRs widely used in studies (Vardhini et al., 2006).

In addition to their significance in general plant growth and development, BRs perform a variety of physiological roles in guarding against abiotic stress, including high and low temperatures (Janeczko et al., 2011; Wang et al., 2014b), salinity (Abbas et al., 2013), light (Wang et al., 2010), drought (Mahesh et al., 2013), and herbicides and pesticides (Xia et al., 2006; Sharma et al., 2013).

One of the main reactions of plants when subjected to stress is the elevated generation of ROS. These include the radicals superoxide $\left(\mathrm{O}_{2}^{-}\right)$, hydroxyl $\left(\mathrm{OH}^{-}\right)$, perhydroxyl $\left(\mathrm{HO}_{2}{ }^{-}\right)$, alkoxy (RO), as well as the non-radicals hydrogen peroxide $\left(\mathrm{H}_{2} \mathrm{O}_{2}\right.$ ) and singlet oxygen $\left(\mathrm{O}_{2}\right)$ (Anjum et al., 2010; Gill and Tuteja 2010; Anjum et al., 2012; Anjum et al., 2015). Plant stress tolerance requires the activation of complex metabolic activities including antioxidant pathways (ROS-scavenging system) within cells, that in turn contribute to plant growth under stress conditions (Elmashad and Mohamed 2012). Plant antioxidant defense systems consist of enzymes such as superoxide (SOD), catalase (CAT), peroxidase (POD), ascorbate peroxidase (APX), glutathione reductase (GR) and glutathione sulfotransferase (GST). Excess of ROS and their reaction products that escape antioxidant-mediated scavenging systems cause oxidative stress, leading to critical damage to the primary metabolites of plants (Anjum et al., 2010, 2012, 2015; Gill and Tuteja, 2010). It is well known that heavy metal phytotoxicity is deeply related to oxidative stress and the consequent production of ROS in plants. Interestingly, antioxidant enzyme activities are also regulated by BRs (Cao et al., 2005). Indeed, BR-induced stress tolerance is associated with an increased expression of genes with antioxidant functions (Xia et al., 2009).

The heavy metal nickel (Ni) is another important environmental contaminant. High concentrations of $\mathrm{Ni}^{2+}$ ions can bind to proteins and lipids inducing oxidative damage (Bal and Kasprzak, 2002). Exogenous application of 24epiBL has been found to ameliorate Ni-stress in Brassica juncea by enhancing the activity of antioxidant enzymes (Kanwar et al., 2013). In the same way, elevated CAT, POD, and SOD activity by exogenous application of 28homoBL protects wheat against Ni toxicity (Yusuf et al., 2010). Elevated antioxidant activity in response to $\mathrm{Ni}$ was also found in Raphanus sativus and Vigna radiate pretreated with 24-epiBL (Sharma et al., 2011a; Yusuf et al., 2012).

Cadmium (Cd) is known to be toxic even at a very low concentrations as it accumulates in edible parts of growing plants, thereby endangering crop yield and quality
(Vázquez et al., 2013). Foliar application of homoBL improves Cd-tolerance in Brassica juncea by increasing activity of antioxidant enzymes (CAT, POD and SOD) (Hayat et al., 2007). Using Phaseolus vulgaris as a model, enhanced $\mathrm{Cd}$ tolerance was possible with exogenous application of 24-epiBL (Rady, 2011). In tomatoes, reduced damage by $\mathrm{Cd}$ was reported with application of 28homoBL/24-epiBL (Hasan et al., 2011). The exogenous application of BRs in Cd-stressed Solanum lycopersicum plants enhanced antioxidant system activity and improved fruit yield and quality (Hayat, 2012). A similar effect was reported using 28-homoBL in the protection of Cicer arietinum against $\mathrm{Cd}$ (Hasan et al., 2008).

Copper $(\mathrm{Cu})$ is an essential transition metal, and an indispensable component in a diverse range of plant metabolic reactions. Furthermore, $\mathrm{Cu}$ has become increasingly hazardous due to its inclusion in fungicides, fertilizers and pesticides (Sonmez et al., 2006). BR treatment mitigates the effect of excess $\mathrm{Cu}$ by reducing $\mathrm{H}_{2} \mathrm{O}_{2}$ content and increasing CAT, POD, and SOD activities in Brassica juncea and Raphanus sativus plants (Fariduddin et al., 2009; Kapoor et al., 2014). Supplementation of BRs also helps plants to enhance antioxidant enzymatic activities in response to other heavy metals such as zinc (Arora and Bhardwaj, 2010; Ramakrishna and Rao, 2013), lead (Anuradha and Rao, 2007; Rady and Osman, 2012) and chromium (Choudhary et al., 2011; Sharma et al., 2011b).

These results all suggest that BRs play a crucial role in response to heavy metal toxicity (Figure 1C). Their ability to improve the effectiveness of antioxidant systems by elevating the activity and levels of enzymatic and nonenzymatic antioxidants has made their use a potential strategy for increasing crop resistance to heavy metal stress.

\section{Ethylene}

The plant growth hormone ethylene is involved in many developmental processes, such as the "triple response" in seedlings (leaf abscission, fruit ripening and senescence). Several studies have reported the involvement of this phytohormone in response to abiotic stress, and previous experiments have shown an increased production of ethylene in plants exposed to toxic levels of heavy metals (Maksymiec, 2007; DalCorso et al., 2010; Khan et al., 2015). However, the way in which ethylene regulates mechanisms of heavy metal tolerance remains unclear.

Ethylene is synthesized from methionine, which is converted to S-adenosylmethionine (SAM) by SAM synthetase. SAM, as a substrate, is capable of forming 1aminocyclopropane-1-carboxylic acid (ACC) by ACC synthase (ACS). This is the rate-limiting step in the ethylene biosynthesis pathway and ultimately releases 5'-methylthioadenosine (MTA), which is recycled again to methionine via the so-called "Yang cycle." However, in the presence of $\mathrm{O}_{2}, \mathrm{ACC}$ is degraded by ACC oxidase (ACO) 
to form ethylene, $\mathrm{CO}_{2}$ and cyanide in plants (Yang and Hoffman, 1984). The enzymes ACS and ACO are the two fundamental components of ethylene biosynthesis. Heavy metal stress increases the expression of genes encoding these two proteins, resulting in higher phytohormone production (Schellingen et al., 2014; Khan et al., 2015).

Copper $(\mathrm{Cu})$ has been found to induce the expression of the ACS genes in potatoes, and in the same way, different varieties of tobacco accumulated ACS transcripts under $\mathrm{Cu}$ exposure (Schlagnhaufer et al., 1997).

Transcriptome analysis of chromium $(\mathrm{Cr})$-treated rice roots showed increased expression of four ethylene biosynthesis-related genes (ACS1, ACS2, ACO4, and ACO5), indicating the participation of ethylene in $\mathrm{Cr}$ signaling in rice (Steffens, 2014; Trinh et al., 2014). Cadmium (Cd) induced the biosynthesis of ACC and ethylene in Arabidopsis thaliana via the increased expression of ACS2 and ACS6 (Schellingen et al., 2014). These results were confirmed by observations in acs2-1acs6-1 double knockout mutants, which showed a decrease in ethylene production. The reduced amount of phytohormone affected leaf biomass and resulted in a delayed induction of ethylene responsive genes without significant differences in $\mathrm{Cd}$ content between wild-type and mutant plants, indicating that the decrease in ethylene production in mutants is not related to a lower Cd uptake (Figure 1D).

Together, these findings demonstrate that under heavy metal stress conditions, plants show a rapid increase in ethylene production and reduced plant growth and development, indicating a strong involvement of this phytohormone in plant response to heavy metal toxicity (Maksymiec, 2007; Schellingen et al., 2014).

Under heavy metal exposure, the enzymes of ethylene biosynthesis, ACS2 and ACS6, are phosphorylated by MAPKs, which in turn increase their half-life. Both phosphorylated and native ACS forms are functional, however the former is more stable and active compared to the latter (Liu and Zhang 2004; Joo et al., 2008; Skottke et al., 2011). Moreover, MPK3 and MPK6 are able to phosphorylate the transcription factor WRKY33, which in turn regulates ACS2 2 and ACS6 gene expression. The WRKY33 protein binds directly to the W-boxes in the promoters of $A C S 2$ and ACS6 genes in vivo, suggesting that WRKY33 also activates $A C S 2$ and ACS6 expression downstream of the MPK3/MPK6 cascade (Li et al., 2012). It is important to emphasize that most studies have focused on $A C S$ or $A C O$ gene expression levels, although other levels of regulation, such as post-transcriptional and post-translational modifications, can affect the abundance of enzyme activity under heavy metal exposure (Figure 1D).

The Arabidopsis EIN2 gene is an important component of the ethylene signaling pathway and acts as a transducer of ethylene and stress responses (Alonso et al., 1999). Cao et al. (2009) showed that lead (Pb) treatment increased transcript levels of EIN2 in Arabidopsis seedlings, indicat- ing a putative role of the gene in heavy metal tolerance (Figure 1D). They also reported that in several developmental stages, there was no difference between an ein2-1 mutant and wild-type seedlings. However, when grown on culture medium containing different concentrations of $\mathrm{Pb}$, the ein 2-1 mutants were more sensitive to the metal than wild-type seedlings (Cao et al., 2009).

The efflux pump at the plasma membrane is one of the most important mechanisms contributing to $\mathrm{Pb}$ resistance in Arabidopsis, and the AtPDR 12 is an $\mathrm{ABC}$ membrane-transporter gene that excludes $\mathrm{Pb}$ and $\mathrm{Pb}$-containing compounds from the cytoplasm (Lee et al., 2005). In ein2-1 mutant seedlings the transcript levels of AtPDR12 were lower than in wild-type plants either in the absence or presence of $\mathrm{Pb}$ (Lee et al., 2005). This result leads to infer that the EIN2 gene may be involved in the regulation of the AtPDR 12 gene, and that the increased sensitivity of ein2-1 mutant seedlings to $\mathrm{Pb}$ is, at least partially, correlated with reduced expression of the AtPDR12 gene. However, it is still not known how the EIN2 gene mediates the expression of AtPDR12 (Cao et al., 2009) (Figure 1D).

There are also some interesting results showing that Arabidopsis ethylene-insensitive etr 1-1 and ein 3-3 mutants are less sensitive to lithium than wild type plants (Bueso et al., 2007). The genes ETR1 and EIN3 act in the ethylene signaling pathway as a receptor and a transcription factor, respectively (Wang et al., 2002). This controversial result may be attributed to metal-specific properties, or differences in the experimental conditions such as metal concentration, exposure time, plant species and developmental stage.

Despite progress made in recent years, more work is required in order to gain a better understanding of ethylene biology and its relationship with heavy metal stress tolerance in a molecular and physiological context. This will increase our knowledge of the molecular mechanisms of plant response to heavy metal toxicity.

\section{Future Perspectives}

Increasing efficiency in the use of resources, improving the quality of agricultural products, and the preservation of natural resources are key challenges facing modern agriculture. Environmental stresses, either natural or anthropogenic, can significantly reduce the potential of crop yields and restrict the sites and soils where commercially important species can be grown. Abiotic stresses such as drought, excessive rainfall, very high or low temperatures, low light, and heavy metal toxicity, are a constant threat to the development of agricultural practices.

The increase of heavy metals in various terrestrial and aquatic ecosystems has led to concerns relating to the spread of these elements in concentrations that could compromise the quality of the environment. Recently, much attention has been given to the development of strategies designed to alleviate the adverse effects of heavy metal tox- 
Table 1 - Interrelation between phytohormone and heavy metal treatments.

\begin{tabular}{|c|c|c|c|c|}
\hline Hormones & Treatment & Effect & Plant & References \\
\hline \multirow[t]{18}{*}{ ABSCISIC ACID } & \multirow[t]{3}{*}{$\mathrm{Cd}$} & \multirow[t]{3}{*}{ Increased endogenous ABA levels } & $\begin{array}{l}\text { Typha latifolia and } \\
\text { Phragmites australis }\end{array}$ & Fediuc et al. (2005) \\
\hline & & & Potato tubers & Stroiñski et al. (2010) \\
\hline & & & Rice plants & Kim et al. \\
\hline & $\mathrm{Hg}, \mathrm{Cd}$ and $\mathrm{Cu}$ & Increased $\mathrm{ABA}$ levels & Wheat seeds & Munzuro et al. (2008) \\
\hline & $\mathrm{Cu}$ and $\mathrm{Zn}$ & $\begin{array}{l}\text { Seed germination decreased and } \mathrm{ABA} \\
\text { content increased }\end{array}$ & Cucumbers & Wang et al. (2014c) \\
\hline & $\mathrm{Pb}$ & ABA accumulation & Cicer arietinum & Atici et al. (2005) \\
\hline & $\mathrm{Cu}$ and $\mathrm{Ni}$ & ABA accumulation & Empetrum nigrum & Monni et al. (2001) \\
\hline & As & $\begin{array}{l}\text { Induction of ABA biosynthesis and } \\
\text { signaling genes }\end{array}$ & Rice & Huang et al. (2012) \\
\hline & $\mathrm{V}$ & $\begin{array}{l}\text { Induction of ABA biosynthesis and } \\
\text { signaling genes }\end{array}$ & Rice & Lin et al. (2013) \\
\hline & $\mathrm{Cu}$ and $\mathrm{Zn}$ & $\begin{array}{l}\text { Induction of genes related to ABA sig- } \\
\text { nal transduction }\end{array}$ & Cucumber & Wang et al. (2014) \\
\hline & $\mathrm{Cd}$ & Inhibitory effects on early growth & Arabidopsis thaliana & Sharma and Kumar (2002) \\
\hline & $\mathrm{Ni}$ and $\mathrm{Zn}$ & $\begin{array}{l}\text { Decreased water potential and } \\
\text { stomatal conductance and increased } \\
\text { ABA levels }\end{array}$ & White bean & Rauser and Dumbroff (1981) \\
\hline & $\mathrm{Cd}$ & $\begin{array}{l}\text { Decreased water potential and } \\
\text { stomatal conductance and increased } \\
\text { ABA levels }\end{array}$ & Brassica juncea & Salt et al., 1995 \\
\hline & $\mathrm{Cd}$ & $\begin{array}{l}\text { Decreased relative water uptake rate } \\
\text { whilst stomatal resistance and ABA } \\
\text { content increased }\end{array}$ & White bean & Poschenrieder et al., 1989 \\
\hline & $\mathrm{Cd}$ and $\mathrm{Cu}$ & $\begin{array}{l}\text { Induced MAPK signaling and in- } \\
\text { creased ABA content }\end{array}$ & Rice & Yeh et al. $(2003,2004)$ \\
\hline & $\begin{array}{l}\text { Exogenous ABA appli- } \\
\text { cation }\end{array}$ & $\begin{array}{l}\text { Affected the transport of } \mathrm{Cd} \text { and } \mathrm{Ni} \text { to } \\
\text { the shoots }\end{array}$ & Rice & Rubio et al. (1994) \\
\hline & & $\begin{array}{l}\text { Limited the root-to-shoot translocation } \\
\text { of } \mathrm{Cd}\end{array}$ & Arabidopsis thaliana & $\begin{array}{l}\text { Perfus-Barbeoch et al. } \\
\text { (2002) }\end{array}$ \\
\hline & & $\begin{array}{l}\text { Enhanced heavy metal toxicity, caus- } \\
\text { ing growth inhibition and the } \\
\text { translocation of storage products from } \\
\text { source to sink organs }\end{array}$ & Rice & Moya et al. (1995) \\
\hline \multirow[t]{9}{*}{ AUXIN } & $\mathrm{Cu}$ & $\begin{array}{l}\text { Enhanced auxin activity in both the } \\
\text { meristem and elongation zones }\end{array}$ & Arabidopsis thaliana & Yuan et al. (2013) \\
\hline & B & $\begin{array}{l}\text { PIN1 down-regulation and inhibition } \\
\text { of root elongation. }\end{array}$ & Arabidopsis thaliana & Li et al. (2015) \\
\hline & $\mathrm{Cd}$ & $\begin{array}{l}\text { Induced NO accumulation, repress } \\
\text { auxin transport and reduced root } \\
\text { meristem size }\end{array}$ & Arabidopsis thaliana & Yuan and Huang, (2016) \\
\hline & $\mathrm{Cu}$ & $\begin{array}{l}\text { Increased auxin and decreased NO lev- } \\
\text { els in roots }\end{array}$ & Arabidopsis thaliana & Peto et al. (2011) \\
\hline & As & Changed IAA, NAA and IBA levels & Brassica juncea & Srivastava et al. (2013) \\
\hline & $\mathrm{Cd}$ & Disturbed IAA homeostasis. & Barley & Zelinová et al. (2015) \\
\hline & & Suppressed primary root elongation & Arabidopsis & Besson-Bard et al. (2009) \\
\hline & $\begin{array}{l}\text { Exogenous IAA appli- } \\
\text { cation }\end{array}$ & $\begin{array}{l}\text { Increased the biomass of roots in soil } \\
\text { moderately contaminated with } \mathrm{Pb}\end{array}$ & Helianthus annuus & Liphadzi et al. (2006) \\
\hline & & Improved growth after exposition to & Brassica juncea & Srivastava et al. (2013) \\
\hline
\end{tabular}


Table 1 - cont.

\begin{tabular}{|c|c|c|c|c|}
\hline Hormones & Treatment & Effect & Plant & References \\
\hline & $\begin{array}{l}\text { Exogenous of auxin pre- } \\
\text { cursor }\end{array}$ & $\begin{array}{l}\text { Enhanced plant growth and yield un- } \\
\text { der Cd stress }\end{array}$ & Rice & Farooq et al. (2015) \\
\hline & $\begin{array}{l}\text { Exogenous natural and } \\
\text { synthetic auxin applica- } \\
\text { tion }\end{array}$ & $\begin{array}{l}\text { Increased phytoremediation efficiency } \\
\text { in wastewater treatment }\end{array}$ & $\begin{array}{l}\text { Wetland and } \\
\text { non-wetland }\end{array}$ & Tandon et al. (2015) \\
\hline & $\begin{array}{l}\text { Co-application of sele- } \\
\text { nium (Se) and auxin }\end{array}$ & Reduced As-induced stress & Rice & Pandey and Gupta (2015) \\
\hline & IAA-Asp & $\begin{array}{l}\text { Modulated catalase and peroxidase ac- } \\
\text { tivity, induced protein carbonylation } \\
\text { and decreased hydrogen peroxide con- } \\
\text { centration }\end{array}$ & Pea & Ostrowski et al. (2016) \\
\hline & $\begin{array}{l}\text { Exogenous NAA appli- } \\
\text { cation }\end{array}$ & $\begin{array}{l}\text { Enhanced hemicellulose } 1 \text { content and } \\
\text { the amount of } \mathrm{Cd}^{2+} \text { fixed in the roots }\end{array}$ & Arabidopsis & Zhu et al. (2013) \\
\hline \multirow[t]{16}{*}{ BRASSINOSTEROID } & $\begin{array}{l}\text { Exogenous application } \\
\text { of 24-epiBL }\end{array}$ & $\begin{array}{l}\text { Enhanced the activity of antioxidant } \\
\text { enzymes and ameliorated Ni-stress }\end{array}$ & Brassica juncea & Kanwar et al. (2013) \\
\hline & & & Raphanus sativus & Sharma et al. (2011a) \\
\hline & & & Vigna radiate & Yusuf et al. (2012) \\
\hline & $\begin{array}{l}\text { Exogenous application } \\
\text { of 28-homoBL }\end{array}$ & $\begin{array}{l}\text { Elevated CAT, POD, and SOD activ- } \\
\text { ity, protecting against Ni toxicity }\end{array}$ & Wheat & Yusuf et al. (2010) \\
\hline & $\begin{array}{l}\text { Exogenous application } \\
\text { of homoBL }\end{array}$ & $\begin{array}{l}\text { Improved Cd-tolerance by increasing } \\
\text { activity of antioxidant enzymes } \\
\text { (CAT, POD and SOD) }\end{array}$ & Brassica juncea & Hayat et al. (2007) \\
\hline & $\begin{array}{l}\text { Exogenous application } \\
\text { of } 24 \text {-epiBL }\end{array}$ & Enhanced Cd tolerance & Phaseolus vulgaris & Rady (2011) \\
\hline & $\begin{array}{l}\text { Exogenous application } \\
\text { of } 28 \text {-homoBL/24- } \\
\text { epiBL }\end{array}$ & Reduced damage under $\mathrm{Cd}$ stress & Tomatoes & Hasan et al. (2011) \\
\hline & $\begin{array}{l}\text { Exogenous application } \\
\text { of BRs }\end{array}$ & $\begin{array}{l}\text { Enhanced antioxidant system activity } \\
\text { and improved fruit yield and quality } \\
\text { under Cd stress }\end{array}$ & Solanum lycopersicum & Hayat (2012) \\
\hline & $\begin{array}{l}\text { Exogenous application } \\
\text { with } 28 \text {-homoBL }\end{array}$ & Induced protection against $\mathrm{Cd}$ stress & Cicer arietinum & Hasan et al. (2008) \\
\hline & BR treatment & $\begin{array}{l}\text { Enhanced antioxidant activity under } \\
\text { heavy metal stress }\end{array}$ & Brassica juncea & Fariduddin et al. (2009) \\
\hline & & & Raphanus sativus & Kapoor et al. (2014) \\
\hline & & & Radish & $\begin{array}{l}\text { Ramakrishna and Rao } \\
\text { (2013) }\end{array}$ \\
\hline & & & & Anuradha and Rao (2007) \\
\hline & & & & Choudhary et al. (2011) \\
\hline & & & Tomato & Rady and Osman (2012) \\
\hline & & & Raphanus sativus L. & Sharma et al. (2011b) \\
\hline \multirow[t]{5}{*}{ ETHYLENE } & $\mathrm{Cu}$ & $\begin{array}{l}\text { Induced the expression of the ACS } \\
\text { genes }\end{array}$ & Potatoes & Schlagnhaufer et al. (1997) \\
\hline & $\mathrm{Cr}$ & $\begin{array}{l}\text { Increased expression of four ethylene } \\
\text { biosynthesis-related genes } \\
\text { (ACS1, ACS2, ACO4, and ACO5) }\end{array}$ & Rice & $\begin{array}{l}\text { Steffens (2014) Trinh et al. } \\
\text { (2014) }\end{array}$ \\
\hline & $\mathrm{Cd}$ & $\begin{array}{l}\text { Induced the biosynthesis of ACC and } \\
\text { ethylene }\end{array}$ & Arabidopsis thaliana & Schellingen et al. (2014) \\
\hline & $\mathrm{Pb}$ & Increased transcript levels of EIN2 & Arabidopsis & Cao et al. (2009) \\
\hline & $\mathrm{Li}$ & $\begin{array}{l}\text { Ethylene insensitive } \text { etr } 1-1 \text { and } \text { ein } 3-3 \\
\text { mutants were less sensitive to stress }\end{array}$ & Arabidopsis & Bueso et al. (2007) \\
\hline
\end{tabular}


icity on crops, and the large amount of research in this area has significantly expanded our understanding of molecular mechanisms involved in metal uptake (Kanwar et al., 2013; Roy and McDonald, 2015), transport (Rubio et al., 1994; Lin et al., 2013) and detoxification (Lee et al., 2005; Zhu et al., 2013; Tandon et al., 2015) in plants (Table 1). However, several key components of the complex metalsignaling network in plants are still to be elucidated.

Considering the importance of plant growth hormones (e.g., abscisic acid, auxins, brassinosteroids and ethylene) for alleviating heavy metal stress, further research is expected to contribute to a deeper knowledge on the endogenous regulation of plant hormone metabolism in such harmful conditions. There are several studies already in support of the importance of plant hormones under heavy metal exposure as well as other abiotic stresses. It is also interesting to note that the critical plant tolerance achieved by phytohormones can be promoted directly or indirectly. For example, ethylene signaling is mediated by EIN2, and some studies also show that the EIN2 gene mediates $\mathrm{Pb}$ resistance through AtPDR12, an efflux pump at the plasma membrane. But phytohormone tolerance can also be induced indirectly, as the one promoted by brassinosteroids, which improves antioxidant systems efficiency in removing ROS and, as a consequence, attenuates detrimental effects from heavy metal stress. In the same way, hormonal treatments were not able to overcome the adverse effects of heavy metals on plant nutrient acquisition, but they were able to efficiently inhibit heavy metal incorporation, such as in stomatal closure guided by ABA that ultimately decrease toxic metals uptake and translocation from roots to shoots.

In summary, improving our knowledge of hormone metabolism in plants is critical for the development of new physiological, biochemical and biotechnological approaches towards mitigating the enormous spectra of abiotic stresses we see in today's environment, including heavy metal toxicity. With challenges such as climate change, which is expected to reduce crop yield in many areas, such information could prove critical for maintaining a reliable food supply for an ever-growing human population

\section{Acknowledgments}

This work was financially supported by $\mathrm{CNPq}$ (Conselho Nacional de Desenvolvimento Científico e Tecnológico) and CAPES (Coordenação de Aperfeiçoamento de Pessoal de Nível Superior).

\section{References}

Abbas S, Latif HH and Elsherbiny EA (2013) Effect of 24epibrassinolide on the physiological and genetic changes on two varieties of pepper under salt stress Conditions. Pak J Bot 45:1273-1284.

Agami RA and Mohamed GF (2013) Exogenous treatment with indole-3-acetic acid and salicylic acid alleviates cadmium toxicity in wheat seedlings. Ecotoxicol Environ Saf 94:164171.

Al-Hakimi AMA (2007) Modification of cadmium toxicity in pea seedlings by kinetin. Plant Soil Environ 53:129-135.

Alonso JM, Hirayama T, Roman G, Nourizadeh S and Ecker JR (1999) EIN2, a bifunctional transducer of ethylene and stress responses in Arabidopsis. Science 284:2148-2153.

Anjum NA, Umar S and Chan M-T (2010) Ascorbate-Glutathione Pathway and Stress Tolerance in Plants. Springer, New York, $443 \mathrm{p}$.

Anjum NA, Umar S and Ahmad A (2012) Oxidative Stress in Plants: Causes, Consequences and Tolerance. IK International Publishing House, New Delhi, 545 p.

Anjum NA, Sofo A, Scopa A, Roychoudhury A, Gill SS, Iqbal M, Lukatkin AS, Pereira E, Duarte AC and Ahmad I (2015) Lipids and proteins - Major targets of oxidative modifications in abiotic stressed plants. Env Sci Pollut Res 22:40994121.

Anjum SA, Tanveer M, Hussain S, Shahzad B, Ashraf U, Fahad S, Hassan W, Jan S, Khan I, Saleem MF, et al. (2016) Osmoregulation and antioxidant production in maize under combined cadmium and arsenic stress. Environ Sci Pollut Res $1-12$.

Anuradha S and Rao SSR (2007) Effect of 24-epibrassinolide on the growth and antioxidant enzyme activities in radish seedlings under lead toxicity. Indian J Plant Physiol 12:396-400.

Arora M, Kiran B, Rani S, Rani A, Kaur B and Mittal N (2008) Heavy metal accumulation in vegetables irrigated with water from different sources. Food Chem 111:811-815.

Arora P and Bhardwaj R (2010) 24-epibrassinolide induced antioxidative defence system of Brassica juncea $\mathrm{L}$. under $\mathrm{Zn}$ metal stress. Physiol Mol Biol Plants 16:285-293.

Atici Ö, Agar G and Battal P (2005) Changes in phytohormone contents in chickpea seeds germinating under lead or zinc stress. Biol Plant 49:215-222.

Bajguz A (2002) Brassinosteroids and lead as stimulators of phytochelatins synthesis in Chlorella vulgaris. J Plant Physiol 159:321-324.

Bal W and Kasprzak KS (2002) Induction of oxidative DNA damage by carcinogenic metals. Toxicol Lett 127:55-62.

Bartels D and Sunkar R (2005) Drought and salt tolerance in Plants. CRC Crit Rev Plant Sci 24:23-58.

Besson-Bard A, Gravot A, Richaud P, Auroy P, Taconnat L, Renou J, Pugin A and Wendehenne D (2009) Nitric oxide contributes to cadmium toxicity in Arabidopsis by promoting cadmium accumulation in roots and by up-regulating genes related to iron uptake. Plant Physiol 149:1302-1315.

Beyer WN, Green CE, Beyer M and Chaney RL (2013) Phytotoxicity of zinc and manganese to seedlings grown in soil contaminated by zinc smelting. Environ Pollut 179:167-176.

Bielen A, Remans T, Vangronsveld J and Cuypers A (2013) The influence of metal stress on the availability and redox state of ascorbate, and possible interference with its cellular functions. Int J Mol Sci 14:6382-6413.

Bueso E, Alejandro S, Carbonell P, Perez-Amador MA, Fayos J, Bellés JM, Rodriguez PL and Serrano R (2007) The lithium tolerance of the Arabidopsis cat 2 mutant reveals a cross-talk between oxidative stress and ethylene. Plant J 52:10521065.

Burnett EC, Desikan R, Moser RC and Neill SJ (2000) ABA activation of an MBP kinase in Pisum sativum epidermal peels 
correlates with stomatal responses to ABA. J Exp Bot 51:197-205.

Camacho-Cristóbal JJ, Martín-Rejano EM, Herrera-Rodríguez MB, Navarro-Gochicoa MT, Rexach J and González-Fontes A (2015) Boron deficiency inhibits root cell elongation via an ethylene/auxin/ROS-dependent pathway in Arabidopsis seedlings. J Exp Bot 66:3831-3840.

Cao S, Xu Q, Cao Y, Qian K, An K, Zhu Y, Binzeng H, Zhao H and Kuai B (2005) Loss-of-function mutations in DET2 gene lead to an enhanced resistance to oxidative stress in Arabidopsis. Physiol Plant 123:57-66.

Cao S, Chen Z, Liu G, Jiang L, Yuan H, Ren G, Bian X, Jian H and Ma X (2009) The Arabidopsis Ethylene-Insensitive 2 gene is required for lead resistance. Plant Physiol Biochem 47:308312 .

Chan Z (2012) Expression profiling of ABA pathway transcripts indicates crosstalk between abiotic and biotic stress responses in Arabidopsis. Genomics 100:110-115.

Choudhary SP, Kanwar M, Bhardwaj R, Gupta BD and Gupta RK (2011) Epibrassinolide ameliorates Cr (VI) stress via influencing the levels of indole-3-acetic acid, abscisic acid, polyamines and antioxidant system of radish seedlings. Chemosphere 84:592-600.

Clemens S (2001) Molecular mechanisms of plant metal tolerance and homeostasis. Planta 4:475-486.

Clemens S and Ma JF (2016) Toxic heavy metal and metalloid accumulation in crop plants and foods. Annu Rev Plant Biol 67:489-512.

Colebrook EH, Thomas SG, Phillips AL and Hedden P (2014) The role of gibberellin signalling in plant responses to abiotic stress. J Exp Biol 217:67-75.

DalCorso G, Farinati S and Furini A (2010) Regulatory networks of cadmium stress in plants. Plant Signal Behav 5:663-667.

Danquah A, de Zelicourt A, Colcombet J and Hirt H (2014) The role of ABA and MAPK signaling pathways in plant abiotic stress responses. Biotechnol Adv 32:40-52.

Ebbs SD, Bradfield SJ, Kumar P, White JC, Musante C and Ma X (2015) Accumulation of zinc, copper, or cerium in carrot (Daucus carota) exposed to metal oxide nanoparticles and metal ions. Environ Sci Nano 3:114-126.

El-mashad AAA and Mohamed HI (2012) Brassinolide alleviates salt stress and increases antioxidant activity of cowpea plants (Vigna sinensis). Protoplasma 249:625-635.

El-Monem A, Sharaf AE-MM, Farghal II and Sofy MR (2009) Role of gibberellic acid in abolishing the detrimental effects of $\mathrm{Cd}$ and $\mathrm{Pb}$ on broad bean and lupin plants. Res J Agric Biol Sci 5:6-13.

Fariduddin Q, Yusuf M, Hayat S and Ahmad A (2009) Effect of 28-homobrassinolide on antioxidant capacity and photosynthesis in Brassica juncea plants exposed to different levels of copper. Environ Exp Bot 66:418-424.

Farooq H, Asghar HN, Khan MY, Saleem M and Zahir ZA (2015) Auxin-mediated growth of rice in cadmium-contaminated soil. Turkish J Agric For 39:272-276.

Fediuc E, Lips SH and Erdei L (2005) O-acetylserine (thiol) lyase activity in Phragmites and Typha plants under cadmium and $\mathrm{NaCl}$ stress conditions and the involvement of $\mathrm{ABA}$ in the stress response. J Plant Physiol 162:865-872.

Finkelstein R (2013) Abscisic acid synthesis and response. Arabidopsis Book 11:e0166.
Galvez-Valdivieso G, Fryer MJ, Lawson T, Slattery K, Truman W, Asami T, Davies WJ, Jones AM, Baker NR and Mullineaux PM (2009) The high light response in Arabidopsis involves ABA signaling between vascular and bundle sheath cells. Plant Cell 21:2143-2162.

Gangwar S, Singh VP, Prasad SM and Maurya JN (2010) Modulation of manganese toxicity in Pisum sativum L. seedlings by kinetin. Sci Hortic 126:467-474.

Gautam S, Anjani K and Srivastava N (2016) In vitro evaluation of excess copper affecting seedlings and their biochemical characteristics in Carthamus tinctorius L. (variety PBNS12). Physiol Mol Biol Plants 22:121-129.

Ghavri SV and Singh RP (2012) Growth, biomass production and remediation of copper contamination by Jatropha curcas plant in industrial wasteland soil. J Environ Biol 33:207214.

Gill SS and Tuteja N (2010) Reactive oxygen species and antioxidant machinery in abiotic stress tolerance in crop plants. Plant Physiol Biochem 48:909-930.

Hac-Wydro K, Sroka A and Jablo K (2016) The impact of auxins used in assisted phytoextraction of metals from the contaminated environment on thea alterations caused by lead (II) ions in the organization of model lipid membranes. Colloids Surfaces B Biointerfaces 143:124-130.

Hasan SA, Hayat S and Ahmad A (2011) Brassinosteroids protect photosynthetic machinery against the cadmium induced oxidative stress in two tomato cultivars. Chemosphere 84:1446-1451.

Hasan SA, Hayat S, Ali B and Ahmad A (2008) 28-Homobrassinolide protects chickpea (Cicer arietinum) from cadmium toxicity by stimulating antioxidants. Environ Pollut 151:60-66.

Hayat S (2012) Foliar spray of brassinosteroid enhances yield and quality of Solanum lycopersicum under cadmium stress. Saudi J Biol Sci 19:325-335.

Hayat S, Ali B, Hasan SA and Ahmad A (2007) Brassinosteroid enhanced the level of antioxidants under cadmium stress in Brassica juncea. Environ Exp Bot 60:33-41.

Hollenbach B, Schreiber L, Hartung W and Dietz KJ (1997) Cadmium leads to stimulated expression of the lipid transfer protein genes in barley: Implications for the involvement of lipid transfer proteins in wax assembly. Planta 203:9-19.

Hsu YT and Kao CH (2003) Role of abscisic acid in cadmium tolerance of rice (Oryza sativa L.) seedlings. Plant Cell Environ 26:867-874.

Huang TL, Nguyen QTT, Fu SF, Lin CY, Chen YC and Huang HJ (2012) Transcriptomic changes and signalling pathways induced by arsenic stress in rice roots. Plant Mol Biol 80:587608.

Ivanov YV, Kartashov AV, Ivanova AI, Savochkin YV and Kuznetsov VV (2016) Effects of zinc on Scots pine (Pinus sylvestris L .) seedlings grown in hydroculture. Plant Physiol Biochem 102:1-9.

Janeczko A, Oklestková J, Pociecha E, Koscielniak J and Mirek M (2011) Physiological effects and transport of 24-epibrassinolide in heat-stressed barley Heat production. Acta Physiol Plant 33:1249-1259.

Joo S, Liu Y, Lueth A, Zhang S and Life B (2008) MAPK phosphorylation-induced stabilization of ACS6 protein is mediated by the non-catalytic C-terminal domain, which 
also contains the cis-determinant for rapid degradation by the 26S proteasome pathway. Plant J 54:129-140.

Kanwar MK, Bhardwaj R, Chowdhary SP, Arora P, Priyanka Sharma and Kumar S (2013) Isolation and characterization of 24-Epibrassinolide from Brassica juncea L. and its effects on growth, Ni ion uptake, antioxidant defence of Brassica plants and in vitro cytotoxicity. Acta Physiol Plant 35:1351-1362.

Kapoor D, Rattan A, Gautam V, Kapoor N, Bhardwaj R, Kapoor D, Rattan A, Gautam V and Kapoor N (2014) 24-Epibrassinolide mediated changes in photosynthetic pigments and antioxidative defence system of radish seedlings under cadmium and mercury stress. Physiol Biochem 10:110-121.

Khan MIR, Nazir F, Asgher M, Per TS and Khan NA (2015) Selenium and sulfur influence ethylene formation and alleviate cadmium-induced oxidative stress by improving proline and glutathione production in wheat. J Plant Physiol 173:9-18.

Kim Y-H, Khan AL, Kim D-H, Lee S-Y, Kim K-M, Waqas M, Jung H-Y, Shin J-H, Kim J-G and Lee I-J (2014) Silicon mitigates heavy metal stress by regulating P-type heavy metal ATPases, Oryza sativa low silicon genes, and endogenous phytohormones. BMC Plant Biol 14:13.

Knetsch MLW, Wang M, Snaar-Jagalska E and HeimovaaraDijkstrab S (1996) Abscisic acid induces Mitogen-Activated Protein Kinase activation in barley aleurone protoplasts. Plant Cell 8:1061-1067.

Lee M, Lee K, Lee J, Noh EW and Lee Y (2005) AtPDR12 Contributes to lead resistance in Arabidopsis. Plant Physiol 138:827-836.

Li G, Meng X, Wang R, Mao G, Han L, Liu Y and Zhang S (2012) Dual-level regulation of ACC synthase activity by MPK3/MPK6 cascade and its downstream WRKY transcription factor during ethylene induction in Arabidopsis. PLoS Genet 8:e1002767.

Li K, Kamiya T and Fujiwara T (2015) Differential roles of PIN1 and PIN2 in root meristem maintenance under low-B conditions in Arabidopsis thaliana. Plant Cell Physiol 56:12051214.

Lin CY, Trinh NN, Lin CW and Huang HJ (2013) Transcriptome analysis of phytohormone, transporters and signaling pathways in response to vanadium stress in rice roots. Plant Physiol Biochem 66:98-104.

Liphadzi MS, Kirkham MB and Paulsen GM (2006) Auxinenhanced root growth for phytoremediation of sewagesludge amended soil. Environ Technol 27:695-704.

Liu Y and Zhang S (2004) Phosphorylation of 1-aminocyclopropane-1-carboxylic acid synthase by mpk6, a stress-responsive mitogen-activated protein kinase, induces ethylene biosynthesis in Arabidopsis. Plant Cell 16:3386-3399.

Lu Y, Yao H, Shan D, Jiang Y, Zhang S and Yang J (2015) Heavy metal residues in soil and accumulation in maize at longterm wastewater irrigation area in Tongliao, China. J Chem 2015:628280.

Mahesh K, Balaraju P, Ramakrishna B, Seeta S and Rao R (2013) Effect of brassinosteroids on germination and seedling growth of radish (Raphanus sativus L.) under PEG-6000 induced water stress. Am J Plant Sci 4:2305-2313.

Maksymiec W (2007) Signaling responses in plants to heavy metal stress. Acta Physiol Plant 29:177-187.

Mandava NB (1988) Plant growth-promoting brassinosteroids. Annu Rev Plant Physiol Plant Mol Bioi 39:23-52.
Jozefczak M, Remans T, Vangronsveld J and Cuypers A (2012) Glutathione is a key player in metal-induced oxidative stress defences. Int J Mol Sci 13:3145-3175.

Masood A, Khan MIR, Fatma M, Asgher M, Per TS and Khan NA (2016) Involvement of ethylene in gibberellic acid-induced sulfur assimilation, photosynthetic responses, and alleviation of cadmium stress in mustard. Plant Physiol Biochem 104:1-10.

Mathur S, Kalaji HM and Jajoo A (2016) Investigation of deleterious effects of chromium phytotoxicity and photosynthesis in wheat plant. Photosynthetica 54:1-9.

Monni S, Uhlig C, Hansen E and Magel E (2001) Ecophysiological responses of Empetrum nigrum to heavy metal pollution. Environ Pollut 112:121-129.

Moya JL, Ros R and Picazo I (1995) Heavy metal-hormone interactions in rice plants: Effects on growth, net photosynthesis, and carbohydrate distribution. J Plant Growth Regul 14:6167.

Mukhopadhyay M and Mondal TK (2015) Effect of ainc and boron on growth and water relations of Camellia sinensis (L.) O. Kuntze cv. T-78. Natl Acad Sci Lett 38:283-286.

Munzuro Ö, Fikriye KZ and Yahyagil Z (2008) The abscisic acid levels of wheat (Triticum aestivum L. cv. Çakmak 79) seeds that were germinated under heavy metal $\left(\mathrm{Hg}^{++}, \mathrm{Cd}^{++}, \mathrm{Cu}^{++}\right)$ stress. G U J Sci 21:1-7.

Nambara E, Okamoto M, Tatematsu K, Yano R, Seo M and Kamiya Y (2010) Abscisic acid and the control of seed dormancy and germination. Seed Sci Res 20:55-67.

Nanda R and Agrawal V (2016) Elucidation of zinc and copper induced oxidative stress, DNA damage and activation of defence system during seed germination in Cassia angustifolia Vahl. Environ Exp Bot 125:31-41.

Nishiyama R, Watanabe Y, Fujita Y, Le DT, Kojima M, Werner T, Vankova R, Yamaguchi-Shinozaki K, Shinozaki K, Kakimoto T, et al. (2011) Analysis of cytokinin mutants and regulation of cytokinin metabolic genes reveals important regulatory roles of cytokinins in drought, salt and abscisic acid responses, and abscisic acid biosynthesis. Plant Cell 23:2169-2183.

Noctor G and Foyer CH (1998) Ascorbate and glutathione: Keeping active oxygen under control. Annu Rev Plant Physiol Plant Mol Biol 49:249-279.

Nomura T, Itouga M, Kojima M, Kato Y and Sakakibara H (2015) Copper mediates auxin signalling to control cell differentiation in the copper moss Scopelophila cataractae. J Exp Bot 66:1205-1213.

Ostrowski M, Ciarkowska A and Jakubowska A (2016) The auxin conjugate indole-3-acetyl-aspartate affects responses to cadmium and salt stress in Pisum sativum L . J Plant Physiol 191:63-72.

Pandey C and Gupta M (2015) Selenium and auxin mitigates arsenic stress in rice (Oryza sativa L.) by combining the role of stress indicators, modulators and genotoxicity assay. J Hazard Mater 287:384-391.

Pandolfini T, Gabbrielli R and Ciscato M (1996) Nickel toxicity in two durum wheat cultivars differing in drought sensitivity. J Plant Nutr 19:1611-1627.

Pantin F, Monnet F, Jannaud D, Costa JM, Renaud J, Muller B, Simonneau T and Genty B (2013) The dual effect of abscisic acid on stomata. New Phytol 197:65-72. 
Perfus-Barbeoch L, Leonhardt N, Vavasseur A and Forestier C (2002) Heavy metal toxicity: Cadmium permeates through calcium channels and disturbs the plant water status. Plant $\mathbf{J}$ 32:539-548.

Peto A, Lehotai N, Lozano-Juste J, León J, Tari I, Erdei L and Kolbert Z (2011) Involvement of nitric oxide and auxin in signal transduction of copper-induced morphological responses in Arabidopsis seedlings. Ann Bot 108:449-457.

Poschenrieder C, Gunsé B and Barceló J (1989) Influence of cadmium on water relations, stomatal resistance, and abscisic acid content in expanding bean leaves. Plant Physiol 90:1365-1371.

Rady MM (2011) Effect of 24-epibrassinolide on growth, yield, antioxidant system and cadmium content of bean (Phaseolus vulgaris $\mathrm{L}$.) plants under salinity and cadmium stress. Sci Hortic 129:232-237.

Rady MM and Osman AS (2012) Response of growth and antioxidant system of heavy metal-contaminated tomato plants to 24-epibrassinolide. Afr J Agric Res 7:3249-3254.

Ramakrishna B and Rao SSR (2013) Preliminary studies on the involvement of glutathione metabolism and redox status against zinc toxicity in radish seedlings by. Environ Exp Bot 96:52-58.

Rauser WE and Dumbroff EB (1981) Effects of excess cobalt, nickel and zinc on the water relations of Phaseolus vulgaris. Environ Exp Bot 21:249-255.

Recatala L, Peris M and Sa J (2006) Assessing heavy metal sources in agricultural soils of an European Mediterranean area by multivariate analysis. Chemosphere 65:863-872.

Rodriguez E, Santos C, Azevedo R, Moutinho-Pereira J, Correia C and Dias MC (2012) Chromium (VI) induces toxicity at different photosynthetic levels in pea. Plant Physiol Biochem 53:94-100.

Roy M and McDonald LM (2015) Metal uptake in plants and health risk assessments in metal-contaminated smelter soils. L Degrad Dev 26:785-792.

Rubio MI, Escrig I, Martinez-Cortina C, Lopez-Benet FJ and Sanz A (1994) Cadmium and nickel accumulation in rice plants. Effects on mineral nutrition and possible interactions of abscisic and gibberellic acids. Plant Growth Regul 14:151-157.

Rui H, Chen C, Zhang X, Shen Z and Zhang F (2016) Cd-induced oxidative stress and lignification in the roots of two Vicia sativa $\mathrm{L}$. varieties with different $\mathrm{Cd}$ tolerances. J Hazard Mater 301:304-313.

Ruzicka K, Ljung K, Vanneste S, Podhorská R, Beeckman TD, Friml J and Benková E (2007) Ethylene regulates root growth through effects on auxin biosynthesis and transport-dependent auxin distribution. Plant Cell 19:2197-2212.

Salt DE, Prince RC, Pickering IJ and Raskin I (1995) Mechanisms of cadmium mobility and accumulation in Indian Mustard. Plant Physiol 109:1427-1433.

Sauter A, Davies WJ and Hartung W (2001) The long-distance abscisic acid signal in the droughted plant: The fate of the hormone on its way from root to shoot. J Exp Bot 52:19911997.

Schat H, Sharma SS and Vooijs R (1997) Heavy metal-induced accumulation of free proline in a metal-tolerant and a nontolerant ecotype of Silene vulgaris. Physiol Plant 101:477482.
Schellingen K, Straeten D Van Der, Vandenbussche F, Prinsen E and Remans T (2014) Cadmium-induced ethylene production and responses in Arabidopsis thaliana rely on ACS2 and ACS6 gene expression. BMC Plant Biol 14:214.

Schlagnhaufer CD, Arteca RN and Pell EJ (1997) Sequential expression of two 1-aminocyclopropane-1-carboxylate synthase genes in response to biotic and abiotic stresses in potato (Solanum tuberosum L .) leaves. Plant Mol Biol 35:683-688.

Sharma S and Kumar V (2002) Responses of wild type and abscisic acid mutants of Arabidopsis thaliana to cadmium. J Plant Physiol 159:1323-1327.

Sharma I, Pati PK and Bhardwaj R (2011a) Effect of 24-epibrassinolide on oxidative stress markers induced by nickelion in Raphanus sativus L. Acta Physiol Plant 33:17231735.

Sharma I, Pati PK and Bhardwaj R (2011b) Effect of 28-homobrassinolide on antioxidant defence system in Raphanus sativus L. under chromium toxicity. Ecotoxicology 20:862874.

Sharma I, Bhardwaj R and Kumar P (2013) Stress modulation response of 24-epibrassinolide against imidacloprid in an elite indica rice variety Pusa Basmati-1. Pestic Biochem Physiol 105:144-153.

Skottke KR, Yoon GM, Kieber JJ and DeLong A (2011) Protein phosphatase $2 \mathrm{~A}$ controls ethylene biosynthesis by differentially regulating the turnover of ACC synthase isoforms. PLoS Genet 7:e1001370.

Sonmez S, Kaplan M, Sonmez NK, Kaya H and Uz I (2006) High level of copper application to soil and leaves reduce the growth and yield of tomato plants. Sci Agric 63:213-218.

Srivastava S, Chiappetta A and Beatrice M (2013) Identification and profiling of arsenic stress-induced miRNAs in Brassica juncea. J Exp Bot 64:303-315.

Steffens B (2014) The role of ethylene and ROS in salinity, heavy metal, and flooding responses in rice. Front Plant Sci 5:685.

Stroinski A, Chadzinikolau T, Gizewska K and Zielezinska M (2010) ABA or cadmium induced phytochelatin synthesis in potato tubers. Biol Plant 54:117-120.

Tandon SA, Kumar R and Parsana S (2015) Auxin treatment of wetland and non-wetland plant species to enhance their phytoremediation efficiency to treat municipal wastewater. J Sci Ind Res 74:702-707.

Thounaojam TC, Panda P, Mazumdar P, Kumar D, Sharma GD, Sahoo L and Panda SK (2012) Excess copper induced oxidative stress and response of antioxidants in rice. Plant Physiol Biochem 53:33-39.

Trinh N, Huang T, Chi W, Fu S and Chen C (2014) Chromium stress response effect on signal transduction and expression of signaling genes in rice. Physiol Plant 150 150:205-224.

Tuteja N (2007) Abscisic acid and abiotic stress signaling. Plant Signal Behav 2:135-138.

Vanneste S and Friml J (2009) Auxin: A trigger for change in plant development. Cell 6:1005-1016.

Vanhoudt N, Vandenhove H, Horemans N, Wannijn J, Bujanic A, Vangronsveld J and Cuypers A (2010) Study of oxidative stress related responses induced in Arabidopsis thaliana following mixed exposure to uranium and cadmium. Plant Physiol Biochem 48:879-886.

Vardhini BV (2014) Brassinosteroids role for amino acids, peptides and amines modulation in stressed plants - A review. 
In: Anjum NA, Gill SS and Gill R (eds) Plant Adaptation to Environmental Change: Significance of Amino Acids and their Derivatives. CAB International, Wallingford, pp 300316.

Vardhini B V, Anuradha S and Rao SSR (2006) Brassinosteroids A great potential to improve crop productivity. Indian $\mathrm{J}$ Plant Physiol 11:1-12.

Vázquez MN, Guerrero YR, González LM and Noval WT de la (2013) Brassinosteroids and plant responses to heavy metal dtress. An overview. Open J Met 3:34-41.

Vernay P, Gauthier-Moussard C and Hitmi A (2007) Interaction of bioaccumulation of heavy metal chromium with water relation, mineral nutrition and photosynthesis in developed leaves of Lolium perenne L. Chemosphere 68:1563-1575.

Vincevica-Gaile Z and Klavins M (2012) Transfer of metals in food chain: An example with copper and lettuce. Environ Clim Technol 10:21-24.

Vreugdenhil D (1983) Abscisic acid inhibits phloem loading of sucrose. Physiol Plant 57:463-467.

Wang KL-C, Li H and Ecker JR (2002) Ethylene biosynthesis and signaling networks. Plant Cell 14:131-152.

Wang M, Jiang W and Yu H (2010) Effects of exogenous epibrassinolide on photosynthetic characteristics in tomato (Lycopersicon esculentum Mill) seedlings under weak light stress. J Agric Food Chem 2010

Wang R, Wang J, Zhao L, Yang S and Song Y (2014a) Impact of heavy metal stresses on the growth and auxin homeostasis of Arabidopsis seedlings. BioMetals 28:123-132.

Wang XH, Shu C, Li HY, Hu XQ and Wang YX (2014b) Effects of $0.01 \%$ brassinolide solution application on yield of rice and its resistance to autumn low-temperature damage. Acta Agric Jiangxi 26:36-38.

Wang Y, Wang Y, Kai W, Zhao B, Chen P, Sun L, Ji K, Li Q, Dai $\mathrm{S}$, Sun $\mathrm{Y}$, et al. $(2014 \mathrm{c})$ Transcriptional regulation of abscisic acid signal core components during cucumber seed germination and under $\mathrm{Cu}^{2+}, \mathrm{Zn}^{2+}, \mathrm{NaCl}$ and simulated acid rain stresses. Plant Physiol Biochem 76:67-76.

Wilkinson S and Davies WJ (2002) ABA-based chemical signalling: The co-ordination of responses to stress in plants. Plant Cell Environ 25:195-210.

Xia XJ, Huang YY, Wang L, Huang LF, Yu YL, Zhou YHZ and Yu JQ (2006) Pesticides-induced depression of photosynthesis was alleviated by 24-epibrassinolide pretreatment in Cucumis sativus L. Pestic Biochem Physiol 86:42-48.

Xia X, Wang Y, Zhou Y, Tao Y, Mao W, Shi K, Asami T, Chen Z and $\mathrm{Yu} J$ (2009) Reactive oxygen species are involved in brassinosteroid-induced stress tolerance. Plant Physiol 150:801-814.

Xu Y-X, Mao J, Chen W, Qian T-T, Liu S-C, Hao W-J, Li C-F and Chen L (2016) Identification and expression profiling of the auxin response factors (ARFs) in the tea plant (Camellia sinensis (L.) O. Kuntze) under various abiotic stresses. Plant Physiol Biochem 98:46-56.
Yang SF and Hoffman NE (1984) Ethylene biosynthesis and its regulation in higher plants. Annu Rev Plant Physiol 35:155189.

Yeh C, Hung W and Huang H (2003) Copper treatment activates mitogen-activated protein kinase signalling in rice. Physiol Plant 119:392-399.

Yeh C, Hsiao L and Huang H (2004) Cadmium activates a mitogen-activated protein kinase gene and MBP kinases in rice. Plant Cell Physiol 45:1306-1312.

Yeh CM, Chien PS and Huang HJ (2007) Distinct signalling pathways for induction of MAP kinase activities by cadmium and copper in rice roots. J Exp Bot 58:659-671.

Yuan H and Huang X (2016) Inhibition of root meristem growth by cadmium involves nitric oxide-mediated repression of auxin accumulation and signalling in Arabidopsis. Plant Cell Environ 39:120-135.

Yuan H, Xu H, Liu W and Lu Y (2013) Copper regulates primary root elongation through PIN1-mediated auxin redistribution. Plant Cell Physiol 54:766-778.

Yusuf M, Fariduddin Q, Hayat S, Hasan SA and Ahmad A (2010) Protective response of 28-Homobrassinolide in cultivars of Triticum aestivum with different levels of nickel. Arch Environ Contam Toxicol 60:68-76.

Yusuf M, Fariduddin Q and Ahmad A (2012) 24-Epibrassinolide modulates growth, nodulation, antioxidant system, and osmolyte in tolerant and sensitive varieties of Vigna radiata under different levels of nickel: A shotgun approach. Plant Physiol Biochem 57:143-153.

Zelinová $\mathrm{V}$, Alemayehu A, Bocová $\mathrm{B}$, Huttová $\mathrm{J}$ and Tamás L (2015) Cadmium-induced reactive oxygen species generation, changes in morphogenic responses and activity of some enzymes in barley root tip are regulated by auxin. Biologia 70:356-364.

Zhang Y, Zheng GH, Liu P, Song JM, Xu GD and Cai MZ (2011) Morphological and physiological responses of root tip cells to $\mathrm{Fe}^{2+}$ toxicity in rice. Acta Physiol Plant 33:683-689.

Zhao H, Wu L, Chai T, Zhang Y, Tan J and Ma S (2012) The effects of copper, manganese and zinc on plant growth and elemental accumulation in the manganese-hyperaccumulator Phytolacca americana. J Plant Physiol 169:1243-1252.

Zhu XF, Jiang T, Wang ZW, Lei GJ, Shi YZ, Li GX and Zheng SJ (2012) Gibberellic acid alleviates cadmium toxicity by reducing nitric oxide accumulation and expression of IRT1 in Arabidopsis thaliana. J Hazard Mater 239:302-307.

Zhu XF, Wang ZW, Dong F, Lei GJ, Shi YZ, Li GX and Zheng SJ (2013) Exogenous auxin alleviates cadmium toxicity in Arabidopsis thaliana by stimulating synthesis of hemicellulose 1 and increasing the cadmium fixation capacity of root cell walls. J Hazard Mater 263:98-403.

\section{Associate Editor: Nelson J. M. Saibo}

License information: This is an open-access article distributed under the terms of the Creative Commons Attribution License (type CC-BY), which permits unrestricted use, distribution and reproduction in any medium, provided the original article is properly cited. 